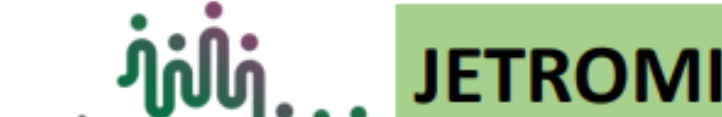 \\ talenta \\ PU BLISHER Infectious Disease
}

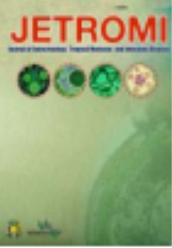

\section{Association of Child-Pugh Score with Renal Dysfunction in Liver Cirrhosis Patients}

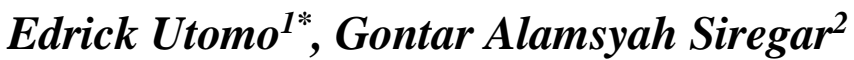 \\ ${ }^{1}$ [Faculty of Medicine, Universitas Sumatera Utara] \\ ${ }^{2}$ [Division of Gastroenterology, Department of Internal Medicine, Universitas Sumatera Utara, Adam \\ Malik Hospital, Medan, Indonesia]
}

\begin{abstract}
.
Background. Renal dysfunction remains a common and serious complication in cirrhotic patients and affects the prognosis of the patient. Early prevention, diagnosis, and treatment are important to avoid any morbidity and mortality caused. This study aims to evaluate the association between the Child-Pugh score and its parameters with renal dysfunction in liver cirrhosis.

Method. This study was a retrospective cross-sectional by design. This study was conducted at Adam Malik General Hospital with a total sampling of liver cirrhosis inpatients in the January 2017-December 2018 periods. A total of 259 patients were included with data collected from the medical record.

Results. The statistical analysis with Chi-square and Fisher's Exact founded an association between Child-Pugh $(\mathrm{p}=0.003)$ and ascites $(\mathrm{p}=0.014)$ with renal dysfunction in liver cirrhosis patients. Meanwhile, hepatic encephalopathy was not found in an association with pvalue $=0.144$. Mann-Whitney test was used to evaluate median differences of albumin, bilirubin, and international internalized ratio (INR) in groups of liver cirrhosis with and without renal dysfunction. The results, albumin was found significant differences with pvalue $=0.017$. Bilirubin and INR were found no significant differences $(p>0.05)$.

Conclusion. There was association significantly between Child-Pugh score with renal dysfunction in liver cirrhosis patients.
\end{abstract}

Keyword: Child-Pugh score, liver cirrhosis, renal dysfunction

\begin{abstract}
Abstrak.
Latar belakang. Disfungsi ginjal tetap merupakan komplikasi yang umum dan serius pada pasien sirosis dan mempengaruhi prognosis pasien. Pencegahan dini, diagnosis, dan pengobatan penting untuk menghindari penyebab morbiditas dan mortalitas sirosis. Studi ini bertujuan untuk mengevaluasi hubungan antara skor Child-Pugh dan parameternya dengan disfungsi ginjal pada sirosis hati.

Metode. Studi ini adalah dengan desain cross-sectional retrospektif. Penelitian ini dilakukan di Rumah Sakit Umum Adam Malik dengan total pengambilan sampel pasien rawat inap sirosis hati pada periode Januari 2017-Desember 2018. Sebanyak 259 pasien termasuk dengan data yang dikumpulkan dari catatan medis.

Hasil. Analisis statistik dengan Chi-square dan Fisher's Exact membentuk hubungan antara Child-Pugh $(p=0,003)$ dan asites $(p=0,014)$ dengan disfungsi ginjal pada pasien sirosis
\end{abstract}

${ }^{*}$ Corresponding author at: Faculty of Medicine, Universitas Sumatera Utara, Medan, North Sumatera, Indonesia

E-mail address: edrickutomo98@gmail.com 
hati. Sementara itu, ensefalopati hati tidak ditemukan dalam hubungan dengan p-value = 0,144. Tes Mann-Whitney digunakan untuk mengevaluasi perbedaan median albumin, bilirubin, dan rasio internal internasional (INR) dalam kelompok sirosis hati dengan dan tanpa disfungsi ginjal. Hasilnya, albumin ditemukan perbedaan yang signifikan dengan pvalue=0.017. Bilirubin dan INR tidak ditemukan perbedaan yang signifikan $(p>0,05)$.

Kesimpulan. Ada hubungan secara signifikan antara skor Child-Pugh dengan disfungsi ginjal pada pasien sirosis hati.

Kata kunci: Child-Pugh score, liver cirrhosis, renal dysfunction

Received 02 September 2021 | Revised 30 November 2021 | Accepted 30 November 2021

\section{Introduction}

Liver cirrhosis is diffuse fibrosis and changes in normal liver architecture with pathological hallmarks such as degeneration and necrosis of hepatocytes, alterations of liver parenchyma with the fibrotic formation and regenerative nodules, and synthetic dysfunction as a final pathway of chronic liver diseases.[1,2] Liver cirrhosis is still a major health problem reported by WHO as ranked eleventh cause of death by the disease worldwide.[3]

Renal dysfunction in liver cirrhosis is a common and problematic occurrence that increases the morbidity and mortality of the patient. Diagnosis is challenging and important as renal dysfunction is more prone to be developed in the cirrhotic patient rather than a non-cirrhotic patient. Hemodynamic stressors that often occur in liver cirrhosis such as hypovolemia (diuretic use, dehydration, or gastrointestinal bleeding) furthermore predispose the occurrences of renal dysfunction in a cirrhotic patient.[4-5] Prevention, early diagnosis, and treatment remain crucial to minimizing morbidity and mortality in maintaining liver cirrhosis patients.[6]

The Child-Pugh score is a prognostic model that can be used to assess the severity of liver cirrhosis. Traditionally developed to predict the prognosis of liver cirrhosis post portal hypertension surgery such as portal caval shunting and transection of the esophagus. Later, the initial score was changed slightly and then includes five parameters: grade of ascites and hepatic encephalopathy, serum bilirubin, albumin, and international normalized ratio (INR). Each parameter valued one to three points later can be divided into three classes: A (5-6 points), B (79 points), and $\mathrm{C}$ (10-15 points). The survival rate decreased accordingly as the score value increased [7].

The study aims to evaluate possible associations between Child-Pugh score and comorbid conditions with renal dysfunction in liver cirrhosis patients and a comparison of laboratory parameters in cirrhotic patients with normal and abnormal renal function.

\section{Method}

This study was a retrospective cross-sectional study with a total sampling of Adam Malik general hospital patients with liver cirrhosis admitted from January 2017 to December 2018. The data 
used are secondary data from patient medical records consisting of the diagnosis, clinical and laboratory findings. The inclusion criteria used were inpatients with liver cirrhosis of any etiologies, older than $\geq 18$ years. Outpatient, pregnant, and or patient medical records that lacked laboratory data such as creatinine or for Child-Pugh score assessment (albumin, bilirubin, and INR) were excluded.

Liver cirrhosis was diagnosed by clinical findings, laboratory, and imaging techniques. Renal dysfunction was defined by increased creatinine serum ( $\mathrm{SCr}$ ) of more than $1.5 \mathrm{mg} / \mathrm{dl}$. The threshold value of $1.5 \mathrm{mg} / \mathrm{dl}$ creatinine serum was used because of a significant decrease in renal function and was used too in defining the hepatorenal syndrome and chronic kidney disease. $[4,8]$

All data were analyzed with SPSS 25 software with univariate and bivariate analytic. Bivariate carried out with statistical methods: Chi-Square and its alternative Fisher Exact, mean comparison independent sample T-test, and median comparison Mann-Whitney test.

\section{Results}

Out of 315 liver cirrhosis inpatients, 259 patients were included in this study where the others were ineligible. Based on table 1 the mean with standard deviation (SD) ages of liver cirrhosis patients was $53 \pm 12$ years. The gender was dominated by males with a 7:3 ratio with the female. Stratified with Child-Pugh classification found Child-Pugh A 14 patients (5.4\%), B 127 patients (49\%), and C 18 patients (45.6\%). Liver cirrhosis patients found with renal dysfunction were 82 patients with $31.7 \%$ prevalence. A total of 99 patients (38.2\%) had hepatitis B and 25 patients (9.7\%) had hepatitis C. 
Table. 1 Liver Cirrhosis Characteristics

\begin{tabular}{lc}
\hline Variables & $\begin{array}{c}\text { Mean } \pm \text { SD or frequency }(\%), \\
\mathbf{n = 2 5 9}\end{array}$ \\
\hline Age & $53 \pm 12$ \\
Gender & \\
Male & $182(70)$ \\
Female & $77(30)$ \\
Child-Pugh classification & \\
A & $14(5.4)$ \\
B & $127(49)$ \\
C & $118(45.6)$ \\
Renal dysfunction & $82(31.7)$ \\
Hepatitis B & $99(38.2)$ \\
Hepatitis C & $25(9.7)$ \\
Ascites & $158(61)$ \\
Pleural effusion & $16(6.2)$ \\
Esophageal varices & $67(25.8)$ \\
With bleeding & $14(5.4)$ \\
Without bleeding & $53(20.5)$ \\
Gastrointestinal bleeding & $45(17.4)$ \\
Hepatic encephalopathy & $30(11.6)$ \\
Infection & \\
Septicemia & $7(2.7)$ \\
Urinary tract infection & $4(1.5)$ \\
Pneumonia & $7(2.7)$ \\
Diabetes mellitus & $35(13.5)$ \\
Hepatocellular carcinoma & $30(11.6)$ \\
Iv diuretic & $91(35.1)$ \\
\hline
\end{tabular}

Ascites were comorbid conditions with the highest prevalence in liver cirrhosis with a total of 158 patients $(61 \%)$. Liver cirrhosis with pleural effusion in 16 patients $(6.2 \%)$, gastrointestinal bleeding in 45 patients (17.4\%), hepatic encephalopathy in 30 patients (11.6\%). Patient with infection: septicemia 7 patients $(2.7 \%)$, urinary tract infection 4 patients $(1.5 \%)$, and pneumonia 7 patients (2.7\%). Diabetes mellitus in liver cirrhosis 35 patients with $13.5 \%$ prevalence. Liver cirrhosis with HCC 30 patients (11.6\%), and intravenous (iv) diuretic use 91 patients (35.1\%). 
Table 2. Laboratory Parameters Comparison in Liver Cirrhosis Patients with and without Renal Dysfunction

\begin{tabular}{|c|c|c|c|}
\hline Variables & $\begin{array}{c}\text { Normal renal } \\
\text { function }(n=177)\end{array}$ & $\begin{array}{c}\text { Renal dysfunction } \\
(\mathbf{n}=\mathbf{8 2})\end{array}$ & p-value \\
\hline Hemoglobin $(\mathrm{g} / \mathrm{dl})^{\mathrm{a}}$ & 9.56 & 9.25 & 0.367 \\
\hline White blood cell $\left(10^{3} / \mu \mathrm{l}\right)^{\mathrm{b}}$ & 6.730 & 9.725 & $0.001^{*}$ \\
\hline Platelet $\left(10^{3} / \mu 1\right)^{\mathrm{b}}$ & 125.000 & 101.000 & $0.040^{*}$ \\
\hline $\mathrm{INR}^{\mathrm{b}}$ & 1.55 & 1.64 & 0.520 \\
\hline Total bilirubin $(\mathrm{mg} / \mathrm{dl})^{\mathrm{b}}$ & 2.8 & 3.2 & 0.462 \\
\hline Direct bilirubin $(\mathrm{mg} / \mathrm{dl})^{\mathrm{b}}$ & 1.5 & 1.65 & 0.151 \\
\hline $\operatorname{ALP}(\mathrm{U} / \mathrm{L})^{\mathrm{b}}$ & 95 & 101 & 0.865 \\
\hline AST/SGOT (U/L)b & 63 & 73.5 & 0.516 \\
\hline ALT/SGPT (U/L) ${ }^{\mathrm{b}}$ & 36 & 41 & 0.142 \\
\hline $\operatorname{Albumin}(\mathrm{g} / \mathrm{dl})^{\mathrm{b}}$ & 2.2 & 2.1 & $0.017 *$ \\
\hline Globulin $(\mathrm{g} / \mathrm{dl})^{\mathrm{b}}$ & 3.5 & 3.2 & 0.755 \\
\hline \multicolumn{4}{|c|}{$\begin{array}{l}\text { aNumeric data with normal distribution: mean, independent sample T-test } \\
\text { bNumeric data with abnormal distribution: median, Mann Whitney test } \\
{ }^{*} \text { Significant (p-value }<0.05 \text { ) }\end{array}$} \\
\hline
\end{tabular}

Table 3. Bivariate Analytic Results

\begin{tabular}{|c|c|c|c|c|}
\hline \multirow{2}{*}{ Variable } & \multicolumn{2}{|c|}{ Renal dysfunction } & \multirow{2}{*}{$\begin{array}{c}\text { OR } \\
\text { (CI 95\%) }\end{array}$} & \multirow{2}{*}{ p-value } \\
\hline & Yes & No & & \\
\hline \multicolumn{5}{|c|}{ Child-Pugh $^{\mathrm{a}}$} \\
\hline A & 0 & 14 & - & $0.003 *$ \\
\hline B & 36 & 91 & & \\
\hline $\mathrm{C}$ & 46 & 72 & & \\
\hline \multicolumn{5}{|l|}{ Ascites $^{b}$} \\
\hline Yes & 59 & 99 & 2 & $0.014 *$ \\
\hline No & 23 & 78 & $1.1-3.6$ & \\
\hline \multicolumn{5}{|c|}{ Esophageal varices ${ }^{b}$} \\
\hline Yes & 17 & 50 & 0.7 & 0.199 \\
\hline No & 65 & 127 & $0.4-1.2$ & \\
\hline \multicolumn{5}{|c|}{ GI bleeding ${ }^{\mathrm{b}}$} \\
\hline Yes & 12 & 33 & 0.7 & 0.428 \\
\hline No & 70 & 144 & $0.4-1.5$ & \\
\hline \multicolumn{5}{|c|}{ Hepatic encephalopathyb } \\
\hline Yes & 12 & 18 & 1.5 & 0.144 \\
\hline No & 70 & 159 & $0.7-3.3$ & \\
\hline \multicolumn{5}{|l|}{ Infection ${ }^{\mathrm{b}}$} \\
\hline Yes & 8 & 9 & 2 & 0.158 \\
\hline No & 74 & 168 & $0.7-5.4$ & \\
\hline \multicolumn{5}{|c|}{ Diabetes mellitus ${ }^{b}$} \\
\hline Yes & 13 & 22 & 1.3 & 0.453 \\
\hline No & 69 & 155 & $0.6-2.8$ & \\
\hline \multicolumn{5}{|l|}{$\mathrm{HCC}^{\mathrm{b}}$} \\
\hline Yes & 13 & 17 & 1.8 & 0.144 \\
\hline No & 69 & 160 & $0.8-3.9$ & \\
\hline \multicolumn{5}{|c|}{ Iv diuretic ${ }^{b}$} \\
\hline Yes & 30 & 61 & 1.1 & 0.739 \\
\hline No & 52 & 116 & $0.6-1.9$ & \\
\hline \multicolumn{5}{|c|}{ Pleural effusion ${ }^{\mathrm{b}}$} \\
\hline Yes & 4 & 12 & 0.7 & 0.554 \\
\hline No & 78 & 165 & $0.2-2.3$ & \\
\hline
\end{tabular}

${ }^{\mathrm{a} F i s h e r ' s ~ E x a c t,}{ }^{\mathrm{b}} \mathrm{Chi}-\mathrm{Square}, *$ significant (p-value $\left.<0.05\right)$ 
Based on table 2. in liver cirrhosis patients were not founded significant differences in hemoglobin mean value with and without renal dysfunction ( $\mathrm{p}$ value $=0.367$ ). Median value comparison of white blood cell $(\mathrm{p}=0.001)$, platelet $(\mathrm{p}=0.040)$ and albumin $(\mathrm{p}=0.017)$ were showed significantly ( $\mathrm{p}$-value $<0.05$ ) between liver cirrhosis patient with and without renal dysfunction. Meanwhile, median comparison of INR ( $\mathrm{p}=0.520)$, total bilirubin $(\mathrm{p}=0.462)$, direct bilirubin $(\mathrm{p}=0.151)$, ALP $(\mathrm{p}=0.151), \operatorname{ALP}(\mathrm{p}=0.865), \operatorname{AST}(\mathrm{p}=0.516), \operatorname{ALT}(\mathrm{p}=0.142)$ and globulin $(\mathrm{p}=0.755)$ were all not showing any significant differences $(p>0.05)$.

There were association founded between Child-Pugh $(\mathrm{p}=0.003)$ and ascites $(\mathrm{p}=0.014)$ with renal dysfunction in liver cirrhosis patients. Esophageal varices, gastrointestinal bleeding, hepatic encephalopathy, infection, diabetes mellitus, HCC, iv diuretic, and pleural effusion have found no association with renal dysfunction in the liver cirrhosis patients ( $\mathrm{p}$-value $>0.05$ ).

There were association founded between Child-Pugh $(\mathrm{p}=0.003)$ and ascites $(\mathrm{p}=0.014)$ with renal dysfunction in liver cirrhosis patients. Esophageal varices, gastrointestinal bleeding, hepatic encephalopathy, infection, diabetes mellitus, HCC, iv diuretic, and pleural effusion have found no association with renal dysfunction in the liver cirrhosis patients (p-value >0.05).

\section{Discussion}

This study found the mean age was $53(\mathrm{SD} \pm 12$ ) years. This result was similar to the previous study by Scaglione et al with a median age of 51.15 years [9]. The progression of viral hepatitis to liver cirrhosis takes 10-20 years [10]. This explained the high age of liver cirrhosis patients as sexually transmitted infections like hepatitis B and C are more prone to be seen in sexually active groups like young adults, which later could develop into liver cirrhosis in the fifth decade of life [11]. Liver cirrhosis patients were dominated by male populations, these findings were similar to the study by Scaglione et al and Aritonang with a male-female ratio of 7:3. The male gender had a higher risk because of differences in behavior and lifestyle, tattoo, illicit drug uses, men's sex with men, and free sex behavior $[9,12]$.

Based on Child-Pugh classifications, cirrhotic patients in this study were dominated by ChildPugh B (49\%) and C (45.6\%). This indicated that liver cirrhosis patient admitted to health care was often advanced. This happened because an early state or compensated liver cirrhosis was often asymptomatic that the patient was not seeking any treatment, this was seen in this study as low Child-Pugh A prevalence only 5.4\%. Change from compensated to decompensated liver cirrhosis is estimated to occur at $5-7 \%$ per year and in this phase decreases of liver function happen gradually and the patient was not aware until decompensation occurs [13,14].

This study found that was an association between Child-Pugh $(\mathrm{p}=0.003)$ with renal dysfunction in liver cirrhosis patients. This shows that in a cirrhotic patient, the higher the severity of liver cirrhosis the more likely to develop renal dysfunction. This finding was similar to the study by 
Choi et al and Bhatti et al $[15,16]$. Ascites itself is one of the parameters used in the Child-Pugh score was found a significant association with renal dysfunction in liver cirrhosis patients with pvalue $=0.014$. The same as Bhatti et al study that was an association found between ascites and renal dysfunction in liver cirrhosis patients ( $\mathrm{p}$-value < 0.001) [16]. Consistently with Qasem et al found that was significant differences in creatinine serum between ascites and without ascites in liver cirrhosis patients ( $p$-value < 0.001) [17]. Another parameter of the Child-Pugh score. albumin was found significant $(\mathrm{p}=0.017)$ differences between liver cirrhosis patients with and without renal dysfunction. Lower albumin level in liver cirrhosis patients is associated with renal dysfunction as linked to ascites formation caused by decreased oncotic pressure [18]. Hepatic encephalopathy has found no association with renal dysfunction in liver cirrhosis patients ( $p$ > 0.05). Same as a study by Jo et al was not founding an association between hepatic encephalopathy in liver cirrhosis groups with and without acute kidney injury [19]. Lastly, another Child-Pugh score parameters: bilirubin and INR have no significant differences $(p>0.05)$ in liver cirrhosis patients with and without renal dysfunction.

Renal dysfunction was common in liver advanced or decompensated liver cirrhosis with ascites and edema. Structural changes in fibrotic tissue will increase intrahepatic pressure which ends with portal hypertension and vasodilator overexpression in the splanchnic area, in advanced: systemic. Ascites was one of the sign indicating splanchnic congestion at the decompensated phase. At this phase, the renin-angiotensin-aldosterone system (RAAS) will be needed to maintain systemic blood pressure caused by ascites and systemic vasodilation. Prolonged RAAS activation will cause sodium and water retention that furthermore worsen the ascites and edema, hypoperfusion, and intrarenal vasoconstriction. Predisposed by a hemodynamic stressor such as fluid loss (diuretic use, dehydration, or bleeding) or infection, RAAS and circulation dysfunction will end in one point in which renal function can't be maintained and renal dysfunction happened [5].

\section{Conclusions}

There was an association found between Child-Pugh score with renal dysfunction in liver cirrhosis patients. A patient with a higher Child-Pugh score is more prone to developing renal dysfunction. Early initiation of prevention, assessment, or treatment must be considered regardless of renal function as early care will decrease possible renal dysfunction incidences, morbidity and mortality caused.

\section{REFERENCES}

[1] S. Nusrat, M. S. Khan, J. Fazili, M. F. Madhoun, "Cirrhosis and its complications: evidence based treatment," World J Gastroenterol, vol. 20, no. 18, pp. 5442-60. 2014.

[2] WC. Zhou, QB. Zhang, L. Qiao, "Pathogenesis of liver cirrhosis," World Journal of Gastroenterol, vol. 20, no. 23, pp. 7312-24. 2014. 
[3] WHO. Global Health Estimates 2015: Deaths by cause, Age, Sex, by Country and by Region, accessed 12 April 2019, Available at: http://www.who.int/healthinfo/global_burden_disease/GHE2015_Deaths_Global_200 0_2015.xls?ua $=1$

[4] N. H. Urrunanga, A. L. Mindikoglu, D. C. Rockey, "Renal dysfunction in cirrhosis," Curr Opin Gastroenterol, vol. 31, no. 3, pp. 215-23. 2015.

[5] T. Bucsics, E. Krones, "Renal dysfunction in cirrhosis: acute kidney injury and the hepatorenal syndrome," Gastroenterology Report, vol. 5, no. 2, pp. 127-37. 2017.

[6] C. Y. Parke, P. Martin, S. Bunnapradist, "Renal dysfunction in cirrhosis," Clinical Liver Disease, vol. 5, no. 6, pp. 150-3. 2015.

[7] M. Pinter, M. Trauner, M. Peck-Radosavljevic, W. Sieghart, "Cancer and liver cirrhosis: implications on prognosis and management," ESMO Open, vol. 1, no. 2, pp. 1-16. 2016.

[8] N. S. Warner, J. A. Cuthbert, R. Bhore, D. C. Rockey, "Acute kidney injury and chronic kidney disease in hospitalized patients with cirrhosis," Journal of Investigative Medicine, vol. 59, no. 8, pp. 1244-51. 2011.

[9] S. Scaglione, S. Kliethermes, G. Cao, D. Shoham, R. Durazo, A. Luke, M. L.et al. "The Epidemiology of Cirrhosis in the United States A Population-based Study," J Clin Gastroenterol, vol. 49, no. 8, pp. 690-6. 2015.

[10] J. Lin, JF. Wu, Q Zhang, HW. Zhang, GW. Cao, "Virus-related liver cirrhosis: Molecular basis and therapeutic options," World J Gastroenterol, vol. 20, no. 21, pp. 6457-69. 2014.

[11] C. H. Mercer, "Sexual behavior," Medicine (Abingdon), vol. 42, no. 6, pp. 291-3. 2014.

[12] M. Aritonang, Karakteristik Penyakit Hepatitis B Kronik pada Pasien Rawat Jalan di RSUP HAM Medan pada Januari 2012 sampai Desember 2013. 2014.

[13] D. N. Samonakis, M. Koulentaki, C. Coucoutsi, A. Augoustaki, C. Baritaki, E. Digenakis, "Clinical outcomes of compensated and decompensated cirrhosis: A long term study," World J Hepatol, vol. 6, no. 7, pp. 504-12. 2014.

[14] A. S. Shah, D. N. Amarapurkar, "Natural History of Cirrhosis of Liver after First Decompensation: A Prospective Study in India," J Clin Exp Hepatol, vol. 8, no.1, pp. 50-7. 2018

[15] Y. J. Choi, J. H. Kim, J. K. Koo, C. I. Lee, J. Y. Lee, J. H. Yang, et al. "Prevalence of renal dysfunction in patients with cirrhosis according to ADQI-IAC working party proposal," Clin Mol Hepatol, vol. 20, no. 2, pp. 185-91. 2014.

[16] H. W. Bhatti, U. Tahir, N. A. Chaudhary, S. Bhatti, M. Hafeez, Z. A. Rizvi, "Factors associated with renal dysfunction in hepatitis C-related cirrhosis and its correlation with Child-Pugh score," BMJ Open Gastroenterol, vol. 6, no. 1, pp. 1-5. 2019.

[17] A. A. Qasem, S. E. Farag, E. Hamed, M. Emara, A. Bihery, H. Pasha, "Urinary biomarker of acute kidney injury in patients with liver cirrhosis," Med Arch, vol. 68, no. 2, pp. 123-6. 2014.

[18] S. Walayat, D. Martin, J. Patel, U. Ahmed, M. N. Asghar, A. U Pai, S. Dhillon, "Role of albumin in cirrhosis: from a hospitalist's perspective," J Community Hosp Intern Med Perspect, vol. 7, no. 1, pp. 8-14. 2017.

[19] S. K. Jo, J. Yang, S. M. Hwang, M. S. Lee, S. H. Park, "Role of biomarkers as predictors of acute kidney injury and mortality in decompensated cirrhosis," Scientific Reports, vol. 9, no. 14508, pp. 1-8. 2019. 